\title{
The extreme drought in the 1920s and its effect on tree growth deduced from tree ring analysis: a case study in North China
}

\author{
Eryuan Lianga,b*, Xuemei Shao ${ }^{\mathrm{a}}$, Zhaochen Kong ${ }^{\mathrm{b}}$ and Jinxing Lin ${ }^{\mathrm{b}}$ \\ ${ }^{a}$ Institute of Geographical Sciences and Natural Resources Research, Chinese Academy of Sciences, 100101, Beijing, P.R. China \\ b Institute of Botany, Chinese Academy of Sciences, 100093, Beijing, P.R. China
}

(Received 14 October 2001; accepted 24 June 2002)

\begin{abstract}
Using tree-ring analysis coupled with historical records, we investigated the possibility of developing a tree-ring network in North China, and the possible disturbance for the dieback of Meyer spruce (Picea meyeri) forest in typical steppe. Four tree-ring chronologies were employed: one for Meyer spruce and Korean spruce (Picea koraiensis) in eastern Inner Mongolia, and two for Chinese pine (Pinus tabulaeformis) in central Inner Mongolia. Significant parallel behaviour between the chronologies revealed the possibility of developing a largescale tree-ring network in North China. In addition, the coincident growth decline in the 1920s in Chinese pine and Korean spruce chronologies revealed the most severe drought period for more than 200 years in North China, which was confirmed by converging lines of historical events. A clear correspondence between a peak in the age distribution (1933-1935) and a persistent drought event from 1922 to 1932 implied that the extreme drought in the 1920s was probably the underlying cause of Meyer spruce mortality.
\end{abstract}

tree ring / historical records / drought / Picea meyeri / North China

Résumé - La sécheresse extrême des années 1920 et son effet sur la croissance des arbres : une étude dendrochronologique en Chine du Nord. La dendrochronologie et l'analyse de documents historiques ont été utilisées d'une part pour évaluer le potentiel d'une base de données dendrochronologiques régionale et d'autre part pour vérifier l'existence d'une perturbation responsable du déclin des forêts d'Épicéa de Meyer (Picea meyeri) dans la steppe typique. Quatre séries dendrochronologiques ont été construites : une pour l'Épicéa de Meyer et l'Epicéa de Corée (Picea koraiensis) dans l'Est de la Mongolie intérieure et deux pour le Pin chinois (Pinus tabulaeformis) en Mongolie intérieure centrale. Les tendances observées dans ces quatre séries dendrochronologiques sont significativement comparables. Ainsi, ces quatre séries suggèrent un fort potentiel pour une base de données dendrochronologiques applicable aux échelles locale et régionale en Chine du Nord. De plus, le Pin chinois et l'Épicéa de Corée ont tous deux montré un déclin de leur croissance dans les années 1920, ce qui indique une période de sécheresse sévère et soutenue inégalée depuis 200 ans en Chine du Nord. Ceci est confirmé par des événements historiques synchrones. Une nette correspondance entre un pic dans la distribution des âges (1933-1935) et une sécheresse soutenue de 1922 à 1935 impliquent que la sécheresse des années 1920 était probablement une des causes de la mortalité de l'Épicéa de Meyer, espèce particulièrement sensible à la sécheresse.

dendrochronologie / documents historiques / sécheresse / Picea meyeri / Chine du Nord

\section{INTRODUCTION}

A small area of Meyer spruce (Picea meyeri Rehd. et Wils) forest in the Xilin River Basin, in sharp contrast to the dominant typical steppe, is considered to be a remnant community of a larger forest established during the forest optimum period in the early Holocene [10]. Meyer spruce forest is currently restricted to cold wet mountainous regions in north-central China, and is clearly out-of-phase with the semi-arid climates in the Xilin River Basin. For this reason, this relict conifer site represents an exceptional opportunity to study ecological features of the natural forest still present in the typical steppe. Although this area of Meyer spruce forest has been mentioned in previous research $[10,13,58]$, few studies have focused on this forest stand. Only recently have Liang et al. [30] evaluated climate-growth relationships of Meyer spruce using tree-ring analysis at this site. Preliminary investigations showed that almost all trees were less than 60 years old [30]. The question was therefore raised as to why this forest stand, as a remnant element of a natural spruce forest from early Holocene, displayed such a young age structure.

Tree-ring analysis, including age structure and dendroecology, proved to be a useful tool in the study of stand dynamics and ecological history of forests $[1,7,14,31,44]$. Despite the

* Correspondence and reprints

E-mail: liangey@igsnrr.ac.cn 
absence of dead trees, stumps, and few old trees dating back to the 1920s in the Meyer spruce forest stand in the typical steppe, other old conifer forest stands can be found around the typical steppe. Thus, a tree-ring database covering a broad range of spatial and temporal scales may provide an alternative approach to assess and understand the stand dynamics of the remnant Meyer spruce forest based on the comparison between the chronology of Meyer spruce and other tree-ring chronologies.

The steppe occupies a large area in northern China, but it has only a restricted distribution of natural forest. Moreover, intensive human activity due to increasing population density, inappropriate land clearing for agriculture and economic pressure in recent centuries have increased the loss of the forest in the semi-arid steppes of northern China, and the forest has become much more fragmented [12]. To date, only disjunctive patches of forests exist as remnants scattering throughout their native range. Remarkably, the steppe in North China represents a large geographic gap with regard to treering data. In addition to Meyer spruce chronology (XLPI) in the typical steppe of the Xilin River Basin, eastern Inner Mongolia, three other chronologies have been constructed in the remnant forest stands, including two Chinese pine (Pinus tabulaeformis Carr) chronologies in Jungar Banner (JGB) and Huhhot (HHT) in an agro-pastoral ecotone of central Inner Mongolia, and one Korean spruce (Picea koraiensis Nakai) chronology (BYAB) from a forest-steppe ecotone in eastern Inner Mongolia. Thus, another question arose as to whether the gap of tree-ring data in the steppe can be bridged by linking the XLPI chronology in typical steppe with the three other chronologies from more distant areas. This connection is crucial for an adequate understanding of the stand history of the Meyer spruce forest in the typical steppe.

The aims of the current study are (i) to make a preliminary assessment of the possible development of a large-scale treering network to fill the gap of tree-ring data in north China; and (ii) to investigate the synchronous disturbances responsible for the young age structure of Meyer spruce in typical steppe by using tree-ring analysis in conjunction with historical records.

\section{MATERIALS AND METHODS}

\subsection{Sampling sites}

The Xilin River Basin (figure 1), located in eastern Inner Mongolia, lies at an altitude varying from $900 \mathrm{~m}$ above sea level (a.s.l.) in the northwestern lower reaches of Xilin River to $1400 \mathrm{~m}$ a.s.l. in the eastern hilly region [6]. A sandy belt with a mean width of $10 \mathrm{~km}$ is situated along the middle reaches of the Xilin River. Perennial and annual grasses are dominant in this region and form a typical steppe landscape. A patch (about 2 ha) of natural Meyer spruce forest $\left(43^{\circ} 42^{\prime} \mathrm{N}, 116^{\circ} 54^{\prime} \mathrm{E}, 1315 \mathrm{~m}\right.$ a.s.l.) is located in the core zone of the UNESCO/MAB (United Nations Educational, Scientific and Cultural Organization/Man and the Biosphere Programme) Xilingol Grassland Nature Reserve in typical steppe of the Xilin River Basin. This patch of conifers contains less than 100 individual trees and grows on the shady slope of an eolian sandy dune situated in the western part of the sandy belt. In August 1994, 42 cores from 21 trees were taken and analyzed [30].
Both Chinese pine forest stands in Huhhot (HHT) and Jungar Banner (JGB) in central Inner Mongolia (figure 1) are also considered to be remnant elements of forests from the early Holocene [12]. The Chinese pine forest (JGB) is adjacent to Agui temple and is located on the north-facing slopes along an east-west loessic hill $\left(39^{\circ} 29^{\prime} \mathrm{N}\right.$, $110^{\circ} 42^{\prime}$ E, $1347 \mathrm{~m}$ a.s.1.) about $1000 \mathrm{~m}$ long. The HHT forest stand is located around Lamadong temple and is restricted to the southern hillside $\left(40^{\circ} 48^{\prime} \mathrm{N}, 111^{\circ} 17^{\prime} \mathrm{E}, 1300 \mathrm{~m}\right.$ a.s.l.) of Da Qingshan (Mts) (the summit is about $2300 \mathrm{~m}$ in elevation). Because of their religious beliefs, the residents tend to protect the temple and the environment surrounding it. Thus, the forests around the temple have escaped logging and other anthropogenic damage, and have persisted throughout the centuries due to the shield-effect of nearby temples.

Korean spruce forest (BYAB) is situated in Baiyunaobao Nature reserve $\left(43^{\circ} 30^{\prime}-43^{\circ} 36^{\prime} \mathrm{N}, 117^{\circ} 04^{\prime}-117^{\circ} 16^{\prime} \mathrm{E}, 1300-1500 \mathrm{~m}\right.$ a.s.l.), in the foothills of Da Hinggan Ling (Mts) (figure 1). This forest stand belongs to the forest-steppe ecotone of eastern Inner Mongolia. The residents believe that these trees are supernatural beings, which prevents the forest from being logged [56]. The taxonomy of this species remains questionable. In this study, Korean spruce was used according to Zhang [57] and Zhao et al. [58].

The samples in HHT and BYAB sites were taken in 1991 and 1988, and the chronologies were constructed in 1994 by Zhang [57]. XLPI and JGB samples were taken in 1994 and 1999 by the authors of this paper.

\subsection{Climatic data}

Climatic data in the Xilin River Basin were obtained from the nearby Xilin Hot Meteorological Station $\left(43^{\circ} 57^{\prime} \mathrm{N}, 116^{\circ} 04^{\prime}\right.$, $991 \mathrm{~m}$ a.s.l.), about $72 \mathrm{~km}$ northwest of the sampled Meyer spruce stand. This meteorological station provided daily precipitation and temperature data recorded continuously since 1951. A typical continental and semiarid temperate steppe climate predominates in the Xilin River Basin [6]. Winter is cold and dry, while summer is warm and wet. The mean annual temperature was about $-0.4{ }^{\circ} \mathrm{C}$ from 1951 to 1994, with mean monthly minimum (January) and maximum (July) temperatures of $-19.5^{\circ} \mathrm{C}$ and $20.8^{\circ} \mathrm{C}$, respectively. The annual precipitation was about $350 \mathrm{~mm}$ for the period 1951 to 1994 with $70 \%$ of rainfall occurring from June to August. The peak precipitation occurs in July. The average frost-free period is 105 days. Moreover, this region is characterized by a large variation of annual precipitation, which fluctuates between $180 \mathrm{~mm}$ and $500 \mathrm{~mm}$. The annual evaporation varies from $1600 \mathrm{~mm}$ to $1800 \mathrm{~mm}$. Prevailing winds are from the north and northwest.

The meteorological stations near HHT and JGB stands are located in Hhhot $\left(40^{\circ} 49^{\prime} \mathrm{N}, 111^{\circ} 41^{\prime}, 1063 \mathrm{~m}\right.$ a.s.l.) and Dongsheng (39 $50^{\prime} \mathrm{N}$, $109^{\circ} 59^{\prime}, 1460 \mathrm{~m}$ a.s.l.), respectively. Annual rainfall in Huhhot and Jungar Banner in central Inner Mongolia is about $400 \mathrm{~mm}$ with $60 \%$ occurrence from June to August. The highest precipitation occurs in August, with one-month lag compared to the eastern region of Inner Mongolia. The annual temperature is around $6-8{ }^{\circ} \mathrm{C}$, mean monthly minimum in January and maximum temperature in July are about $11.8^{\circ} \mathrm{C}$ and $23.3^{\circ} \mathrm{C}$, respectively.

The meteorological station near Baiyunaobao is in Linxi ( $43^{\circ} 36^{\prime} \mathrm{N}, 118^{\circ} 04^{\prime}, 799 \mathrm{~m}$ a.s.l.). The annual rainfall in Baiyunaobao is about $450 \mathrm{~mm}$ with $68 \%$ occurring from June to August. Monthly precipitation shows a pronounced maximum in July. Mean annual temperature is about $-1.4{ }^{\circ} \mathrm{C}$; the minimum temperature occurs in January and the maximum in July with monthly means equal to $-23.4^{\circ} \mathrm{C}$ and $14.7^{\circ} \mathrm{C}$, respectively. The relatively wet and cold climate in this site is more favorable for the growth of spruce than the climate of the typical steppe. 


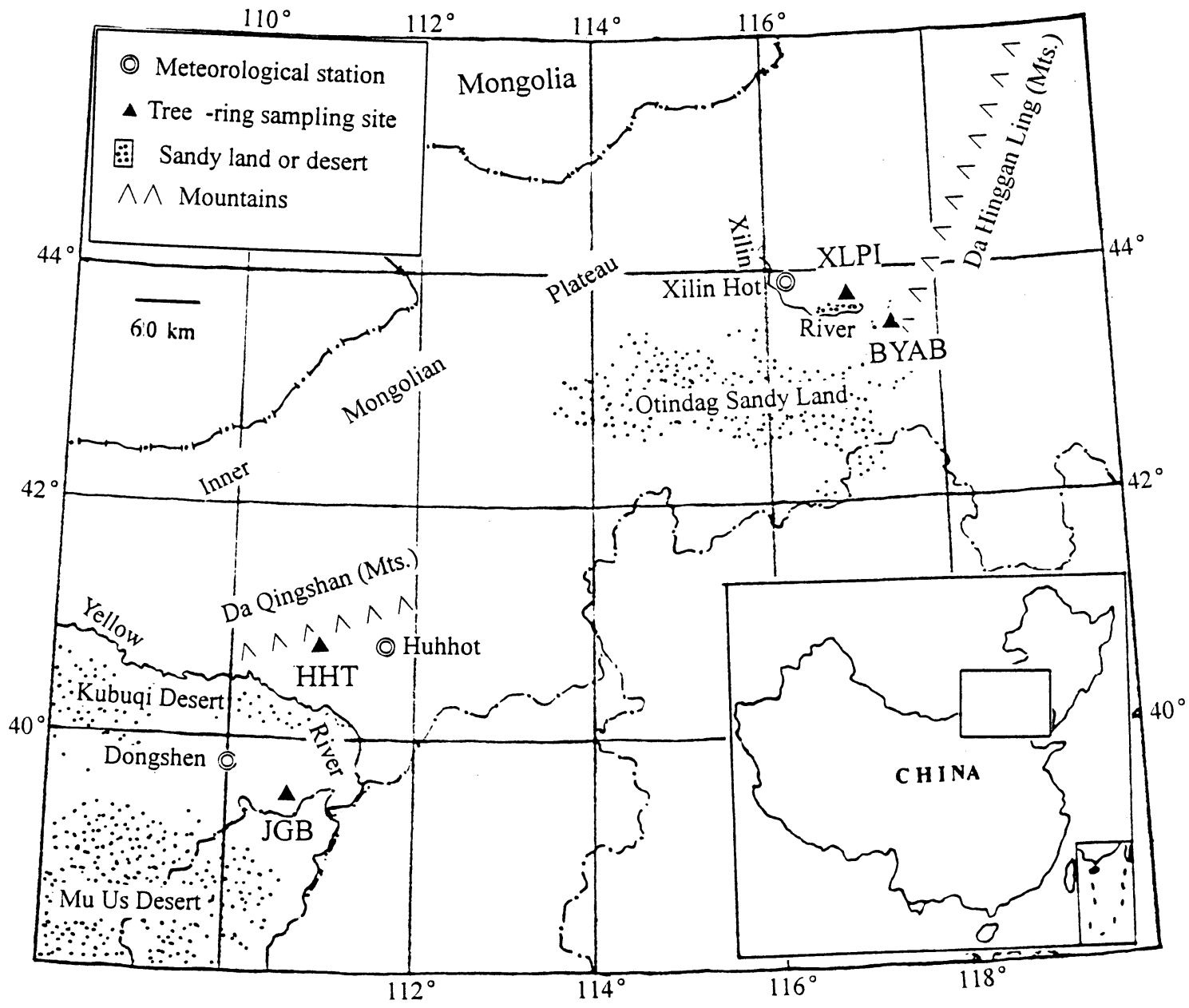

Figure 1. Map of the study area showing the meteorological stations and tree-ring sampling sites in the Xilin River Basin, Baiyunaobao Nature Reserve, Loess Plateau and Da Qingshan (Mts). Meyer spruce site (XLPI) is located on sandy land in the typical steppe of the Xilin River Basin; Korea spruce site (BYAB) is from the forest-steppe ecotone in eastern Mongolia. Chinese pine site (JGB) in Jungar Banner is close to Mu Us and Kubuqi deserts on the Loess Plateau; Chinese pine site (HHT) is in the Da Qingshan, near the margin of Loess plateau. The two Chinese pine sites (JGB and HHT) are located in the agro-pastoral ecotone in central Inner Mongolia.

Table I. Site description and general characteristics of the four tree-ring width standardized chronologies. $R_{\mathrm{S}}$ and SNR represent the signal to noise ratio and the correlation between the series (See Liang et al. 2001, for a description of these statistics).

\begin{tabular}{ccccccc}
\hline Chronology & Species & Elevation m a.s.l. & Time span & Trees/cores & $R_{\mathrm{S}}$ & SNR \\
\hline BYAB & Korean spruce & 1400 & $1863-1988$ & $11 / 22$ & 0.519 & 11.35 \\
HHT & Chinese pine & 1300 & $1622-1991$ & $19 / 38$ & 0.503 & 17.68 \\
JGB & Chinese pine & 1347 & $1850-1998$ & $24 / 50$ & 0.748 & 67.67 \\
XLPI & Meyer spruce & 1315 & $1930-1994$ & $21 / 39$ & 0.467 & 14.44 \\
\hline
\end{tabular}

\subsection{Methods}

The cores were visually crossdated on the basis of ring-width patterns $[11,16,46]$. Annual radial increments were measured to the nearest $0.01 \mathrm{~mm}$ using a digitizing tablet interfaced with a computer. The absolute ring dating was subsequently assessed by using a COFECHA computer program [20]. This procedure resulted in the elimination of 12 cores for the JGB site (out of a total of 62 cores from 30 dominant trees) and 60 cores for the HHT site (out of a total of 98 cores from 48 trees). Twenty-two cores from 11 trees in the BYAB site remained and 3 short cores were eliminated in the XLPI site (out of a total of 42 cores from 21 trees).

Ring width series were further standardized using the cubic smoothing spline to eliminate tree specific growth trends that resulted 


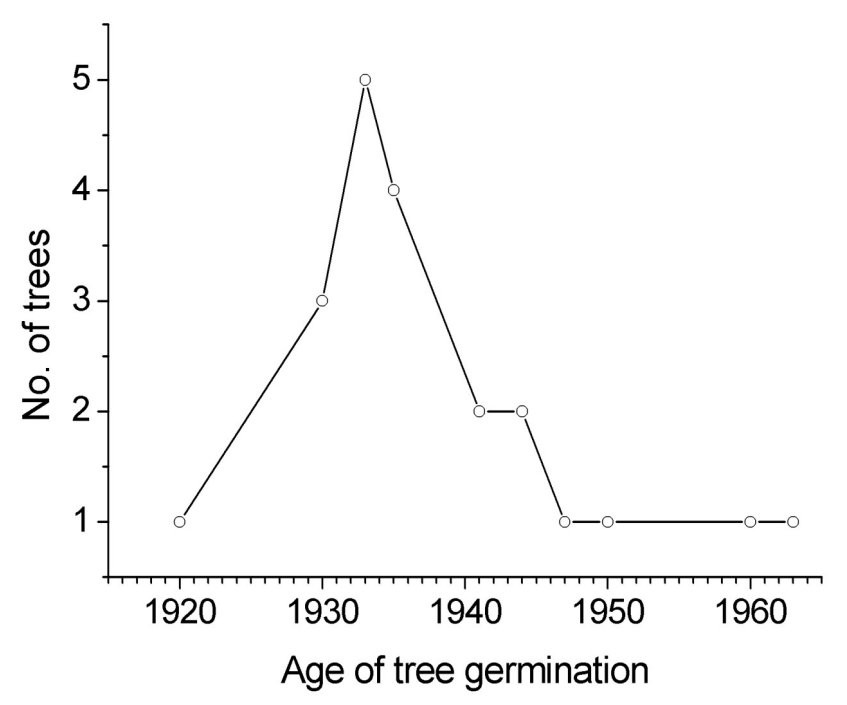

Figure 2. Age distribution of 21 Meyer spruce trees with a diameter above $20 \mathrm{~cm}$. The increment cores were sampled in August 1994 Tree ages represented here are the possible germination age of trees, which was estimated by adding 10 years to the pith age at the breast height.

from age, size difference and competition [9]. Thus, ring-width measurements of each core were divided by the fitted spline values to produce a standardized tree ring series for each core. These dimensionless index series were then averaged for each site by using the biweight robust mean to develop a standardized chronology for each site. Site description and general characteristics of the four treering width standardized chronologies were summarized in table I.

The age structure of Meyer spruce in the typical steppe was investigated in the field, and the analysis of increment cores from the breast height of 21 trees among the oldest was performed in the laboratory in 1999. The harvesting of seedlings and older trees to estimate growth to breast height was not allowed in the core zone of the natural reserve, the ages of seedlings within the forest boundaries were identified by counting terminal bud scars along the stems in the field. Five additional cores taken at the base of the stem and going close to the pith gave the date of germination of 5 Meyer spruce trees among the oldest, though the earliest collar of the trees and the tree ring formed during the first year of life cannot be identified. After comparing the number of tree rings at the base of the trees and at breast height, the actual age of trees was calculated by adding 10 years to the pith age at breast height.

The synchronization among the four chronologies was checked by the student's t-test to determine the degree of correlation between the four chronologies [16]. The correlation between the chronologies was calculated for a common period (59 years) and a maximum overlap period. Since the existence of a statistically significant correlation was the first step for establishing a tree-ring network and for evaluating the similarity of tree growth patterns, all statistical procedures were evaluated at $P<0.05$ level of significance (t-test).

The percentage of identical growth trends from one year to another was registered as slope equivalence or "Gleichäufigkeit" [5, 47]. This statistical method was frequently applied to evaluate the similarity between the site chronologies $[5,47]$. In this study, the "Gleichäufigkeit" values between the four chronologies were calculated.

Response functions were used to identify the response of radial growth to the precipitation variance [16]. The precipitation data were
Table II. Cross correlations between the four tree-ring width chronologies. $\mathrm{R}$ and $\mathrm{r}$ are the correlation coefficients calculated for the maximum overlap periods and a 59-yr common period, respectively. $\mathrm{G}$ is the slope equivalence (given as \% Gleichläufigkeit). Significance (Student's t-test) at $P=0.05, P=0.01$, and $P=0.001$ levels are respectively indicated by one, two, and three asterisks.

\begin{tabular}{ccccc}
\hline Chronology & BYAB & HHT & \multicolumn{1}{c}{ JGB } & XLPI \\
\hline BYAB & - & $\mathrm{R}=0.263 * *$ & $\mathrm{R}=0.198 *$ & $\mathrm{R}=0.401 * *$ \\
& & $\mathrm{r}=0.345 *$ & $\mathrm{r}=0.227$ & $\mathrm{r}=0.401 * *$ \\
\multirow{5}{*}{ HHT } & & $\mathrm{G}=55.08 \%$ & $\mathrm{G}=50.85 \%$ & $\mathrm{G}=70.69 \%$ \\
& $\mathrm{R}=0.263 * *$ & - & $\mathrm{R}=0.567 * * *$ & $\mathrm{R}=0.214$ \\
& $\mathrm{r}=0.345 *$ & & $\mathrm{r}=0.661 * * *$ & $\mathrm{r}=0.235$ \\
& $\mathrm{G}=55.08 \%$ & & $\mathrm{G}=80.51 \%$ & $\mathrm{G}=61.29 \%$ \\
JGB & $\mathrm{R}=0.198 *$ & $\mathrm{R}=0.567 * * *$ & - & $\mathrm{R}=0.316 * *$ \\
& $\mathrm{r}=0.227$ & $\mathrm{r}=0.661 * * *$ & & $\mathrm{r}=0.342 * *$ \\
& $\mathrm{G}=50.85 \%$ & $\mathrm{G}=80.51 \%$ & & $\mathrm{G}=60.94 \%$ \\
XLPI & $\mathrm{R}=0.401 * *$ & $\mathrm{R}=0.214$ & $\mathrm{R}=0.316 * *$ & - \\
& $\mathrm{r}=0.401 * *$ & $\mathrm{r}=0.235$ & $\mathrm{r}=0.342 * *$ & \\
& $\mathrm{G}=70.69 \%$ & $\mathrm{G}=61.29 \%$ & $\mathrm{G}=60.94 \%$ & \\
\hline
\end{tabular}

from the nearby meteorological stations mentioned above. Thirteen months from August of the year $n-1$ to August of the year $n$ were used. A common period in 41 years (XLPI, JGB and HHT) and 37 years (BYAB) between the precipitation records and the chronologies was calculated.

\section{RESULTS}

\subsection{Age structure of Meyer spruce forest}

Seedlings of Meyer spruce from 1 to 10 years old can be observed in the field by counting the terminal bud scars. The age structure of the 21 old trees showed a good community succession (figure 2). Only one tree was established in the 1920 s and a peak in the age distribution was an evident from 1933 to 1935.

\subsection{The correlation between the four tree-ring chronologies}

Significant correlations existed between adjacent chronologies HHT and JGB $(P<0.001)$, and remote chronologies BYAB and HHT, XLPI and JGB, XLPI and BYAB $(P<0.01)$ (table II), whereas BYAB and JGB chronologies showed a relatively weaker correlation $(P<0.05)$. Similarly, the highest year-to-year consistency in the tree-ring patterns was found between adjacent chronologies HHT and JGB $(80.51 \% \mathrm{G})$, XLPI and BYAB $(70.69 \% \mathrm{G})$. Also, a higher than $60 \%$ Gleichäufigkeit existed between XLPI and two remote chronologies (HHT and JGB).

\subsection{The growth anomalies in the 1920 s and early $1930 \mathrm{~s}$}

A similar tree-ring width pattern was observed in JGB, BYAB and HHT chronologies in the 1920s. JGB chronology exhibited abnormally narrow rings in 1922, 1924-1926 and 1928-1932 compared with other periods (figure 3). 


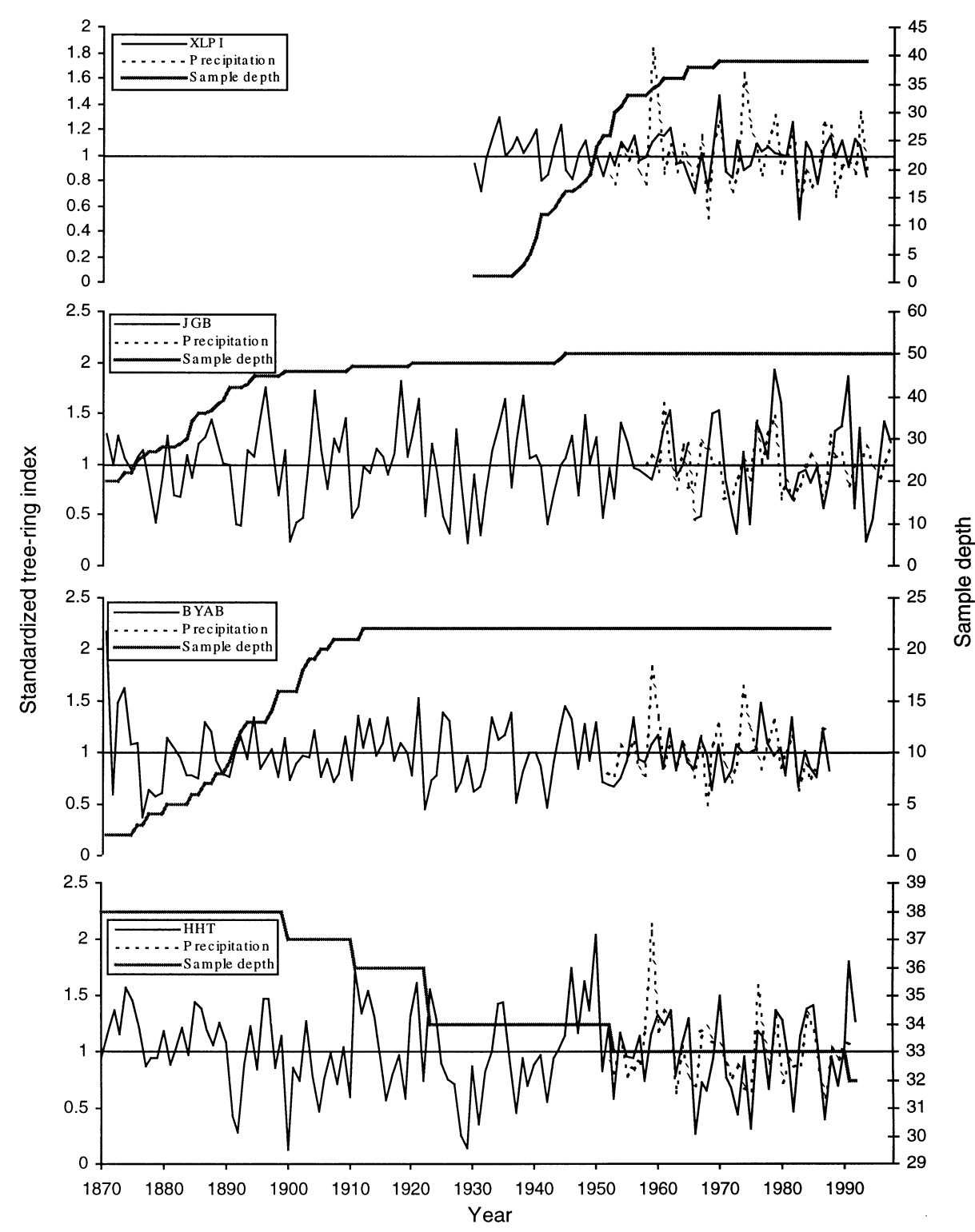

Figure 3. Tree-ring width patterns for the four standardized chronologies considered. Three chronologies (JGB, HHT and BYAB) display a significant growth decline from 1922 to 1932: this period is delineated by two vertical lines. The sample depth and the amount of precipitation from August of the year $n-1$ to August of the year $n$ were plotted against the chronologies. Here, the seasonal precipitation was divided by a long-term mean values to produce standardized data.

$13.11 \%$ missing rings were dated from 1922 to 1932 among all 50 cores. Although no missing rings in BYAB chronology were found, a remarkable below-average growth in the years 1922-1924 and 1927-1932 appeared clearly (figure 3). Likewise, Chinese pine chronology (HHT) also exhibited a significant growth decrease in the years 1922-1932 (figure 3), with $46.08 \%$ missing rings from 1928 to 1931.

The re-analysis of tree-ring data showed that about $65 \%$, $58 \%$ and $70 \%$ of the year-to-year variability in ring-width index of XLPI, BYAB and JGB chronologies could be respectively explained by monthly precipitation for the period ranging from August (year $n-1$ ) to August of the current year $(n)$.

\section{DICUSSION}

\subsection{The implication of age structure of Meyer spruce forest}

As this patch of forest has received little attention, no written records on the stand history are available. The investigation carried out by the Chinese Academy of Science in 1996 confirmed the existence of good community succession in this relict forest stand. A recent study also reported that the young age (less than 70 years) of this forest stand was evident [13]. The shape of the histogram of stand age-classes can yield 
insights into the nature of the disturbance regime [31]. Few older Meyer spruce trees dating before 1930 and a static age structure from 1933 to 1935 seems to have been facilitated by a series of major disturbances to this forest stand in the $1920 \mathrm{~s}$ and early 1930s [25].

\subsection{Correlations among the four tree-ring chronologies}

The parallel behaviour of relatively close chronologies (BYAB and XLPI, HHT and JGB) indicated a general regional synchronization of tree-ring variations. BYAB and HHT forest stands were probably affected by mountainous climates, while XLPI and JGB forest stands were more exposed to a semi-arid climate than the two other stands. The significant teleconnection between BYAB and HHT, XLPI and JGB, and the relatively low correlation between BYAB and JGB, HHT and XLPI suggested the influence of a different topography and local microclimate on tree growth.

The statistically significant correlation between tree-ring chronologies also gives us a high degree of confidence in the reliability of chronological crossdating. These forest stands have not been heavily disturbed nor subjected to high pollution levels [12]. Thus, it seems reasonable to use these chronologies as an important resource for examining climate disturbance events. The spatially coherent pattern of tree-ring series among XLPI, JGB and BYAB chronologies suggested that large-scale climate changes over North China were a major determining factor in the tree-ring variations.

\subsection{The 1920s drought in North China revealed by tree rings}

High-frequency of missing rings in two Chinese pine stands and low-average growth in the Korean spruce stand indicated the incidence of large and deep depressions in the 1920s and the early 1930s. For trees growing in semiarid regions, the width of annual rings is primarily limited by available moisture $[4,15,19,26,27,34-36,42,43,51,53]$. In this study, a high percent of chronology variance accounted for by the precipitation in the four chronologies also revealed the nature of susceptibility of forest stands to drought disturbance. Thus, the comparatively synchronized growth shocks exhibited by Chinese pine and Korean spruce were probably the outcome of the large-scale severe sustained drought which occurred in the 1920s and early 1930s in North China.

A variety of historical and proxy records provided a reference framework for assessing climatic extremes in the 1920s in North China, although few meteorological records can cover this period. The extreme drought severity in the 1920s was also reported in the reconstruction of precipitation fluctuations using tree rings of Pinus armandi in north-central China [21, 48], and of Pinus sibirica and Pinus sylvestris in Mongolia [23, 41]. The gagged-flow record of the Yellow River in Shanxian showed an 11-yr low-flow period from 1922 to 1932 , corresponding to a 7-yr low-flow interval from 1926 to 1932 in Yongding River in Beijing [54]. Daihai Lake in central Inner Mongolia had a surface area of $50 \mathrm{~km}^{2}$ from 1927 to 1929 , compared to a normal area of $134 \mathrm{~km}^{2}$ in 1988 [54]. It was noteworthy that drought-induced famines and disease led to the death of a total estimation of 4 million residents in five provinces including Gansu, Shaanxi, Inner Mongolia, Ningxia Qinghai [54], demonstrating to the intensity and severity of the drought in the 1920s in North China. Archives also demonstrated that this extraordinary drought caused a heavy mortality among old trees, and a substantial loss of domestic livestock in the steppe of eastern Inner Mongolia [57], indicating the extensive influence of the severe persistent drought on the forest and grassland. Overall, converging lines of evidence confirmed the phenomenon deduced from tree-ring analysis that a "worst-case" drought scenario did hit North China in the 1920s and the early 1930s. The 1920s drought has never been exceeded since 1642 [8].

\subsection{The probable cause of Meyer spruce mortality}

The paucity of trees dating from the 1920s in this stand and the immediate forest recruitment in the early 1930s was in accordance with the extreme drought event which occurred in the 1920s and with the following drought release in 1933, suggesting that the severe sustained drought was probably the triggering factor for the dieback of the remnant Meyer spruce forest. There were also numerous reports on drought-induced forest mortality [3, 24, 28, 32, 33, 37, 39, 40, 52].

However, tree mortality may result from multiple factors, including human activity, fire suppression, competition, insect infestation, or a combination of these disturbances [22, 45]. Prior to 1950 , the Xilin River Basin was still a virgin territory, implying that no direct relationship existed between human activity and forest dieback in the 1920s. Fire is considered to be an important disturbance factor modelling the modern boreal landscape [49]. Sustained drought coinciding with high temperatures was generally conductive to the occurrence of fire [18]. However, one important limitation for fire reconstruction is the inability to detect fire-related information in fixed sandy land. Moreover, fire always occurs in early spring, when the wind is extremely strong. Assuming that fires occurred in the 1920 s or early 1930 s, the postfire debris in this relatively high elevation stand would have been removed by strong winds. On the other hand, wild fires in semiarid steppe are frequent, but no fire-scarred trees were observed in this forest stand. A concurrent insect attack during a drought period may also predispose the forest to eventual dieback [2]. Surrounded by typical steppe, this patch of Meyer spruce forest showed no evidence of insect infestation in recent decades, though insects attacked the adjacent BYAB site in the 1960s [56]. It is possible that the microclimate and topography in a such isolated forest stand have contributed to the protection of this patch of forest from the interference of fire and insects in the mortality process. Basically, Meyer spruce mortality was most likely to have been driven by extreme drought.

Chinese pine, Meyer spruce and Korean spruce in different forest stands may show considerably different responses to the 1920s drought. Chinese pine presents strong drought adaptations, including deep roots, xeromorphic leaves, low transpiration caused by a high ratio of bound water to free water in the leaves, and early stomata closure in response to drought stress [55]. It covers a wide ecological spectrum from the Loessic hills and semi-arid sandy lands to $1000-2600 \mathrm{~m}$ (a.s.1.) mountains in North china [55]. Although Chinese pine in JGB site displayed an apparent growth reduction and high-frequency of 
missing rings in response to extreme drought in the 1920s and early 1930s, the prolonged drought did not preclude its survival and recovery. On the contrary, the relatively wet and cold climate at BYAB site may mitigate the impacts of a severe drought on the radial growth of Korean spruce. As a remnant species in the typical steppe, Meyer spruce trees are at their limit of survival owing to general low precipitation, which may determine the sensitivity and vulnerability of relic forests to regional precipitation regimes, even of relatively small magnitude and short duration of drought. The dendroclimatic investigation for Meyer spruce carried out in this stand demonstrated that the radial growth of Meyer spruce was significantly correlated with the precipitation from August to October (year $n-1)$, and with the precipitation of the current May [30]. Short-term drought from August 1982 to June 1983 had contributed to the formation of extremely narrow rings in 1983 [30]. A severe sustained drought for 7 or 11 consecutive years in the 1920s and the early 1930s would have exacerbated the problems caused by the inherent scarcity of water in the typical steppe. Physiologically, the prolonged soil moisture depletion in combination with generally high temperatures might reduce carbohydrate reserves, increase fine root mortality, cause the defoliation and cessation of cambial activity [1, 29], and eventually predispose drought-sensitive Meyer spruce trees to death. This also implies that tree growth responses to the drought are dependent on tree phenotype and ecological distribution $[1,7,17,38,50]$.

The strong linkage between tree-ring chronologies sheds light on the perspective of developing a large-scale tree-ring network in North China. Tree-ring analysis with reference to historical records also indicated that the severe sustained drought in the 1920s was the basic cause of the mortality of the drought-sensitive remnant Meyer spruce in typical steppe. The death of trees was the ultimate stage of a positive feedback process triggered by extreme drought. This research provides new insights into the vulnerability and sensitivity of remnant forests to climate change, and is the first step towards understanding the effects of a potential drought induced by global warming on the remnant forest in typical steppe.

Acknowledgements: This research was supported by Knowledge Innovation Project of CAS, No. KZCX3-SW-321 and KZCX2-314. We are grateful to Lily Wang and Lei Huang for the helpful suggestions (IGSNRR, CAS), Violaine Lafortune (CEN, Québec) and Olivier Chandioux (Cemagref) for the translation of the French abstract and two anonymous reviewers for their constructive suggestions regarding revision of the manuscript.

\section{REFERENCE}

[1] Abrams M.D., Ruffner C.M., Morgan T.A., Tree-ring response to drought across species and contrasting sites in the ridge and valley of central Pennsylvania, For. Sci. 44 (1998) 550-558.

[2] Bergeron Y., Leduc A., Morin H., Joyal C., Balsam fir mortality following the last spruce budworm outbreak in northwestern Québec, Can. J. For. Res. 25 (1995) 1375-1384.

[3] Bert G.D., Impact of ecological factors, climatic stresses, and pollution on growth and health of Silver fir (Abies-Alba Mill) in the Jura Mountains - an ecological and dendrochronological study, Acta Oecologica 14(2) (1993) 229-246.
[4] Biondi F., Climatic signals in tree-rings of Fagus-Sylvatica L from the central Apennines, Italy, Acta Oecologica 14(1) (1993) 57-71.

[5] Bräuning A., Dendrochronology for the last 1400 years in eastern Tibet, GeoJournal 34 (1994) 75-95.

[6] Chen Z., Topography and climate of the Xilin River Basin, in: Inner Mongolia Research Station of Academia Sinica (Ed.), Research on Grassland Ecosystem, Science Press, Beijing, Vol. 3, 1988, pp. 13-22. In Chinese with English summary.

[7] Cherubini P., Piussi P., Schweingruber F.H., Spatiotemporal growth dynamics and disturbances in a subalpine spruce forest in the Alps: a dendroecological reconstruction, Can. J. For. Res. 26 (1996) 991-1001.

[8] Chinese Academy of Meteorological Science, Yearly charts of dryness/wetness in China for the last 500-year period, China Map Press, Beijing, 1981. In Chinese with English summary.

[9] Cook E.R., A time series analysis approach to tree-ring standardization, Ph.D. dissertation, University of Arizona, Tucson, 1985.

[10] Cui H., Liu H., Yao X., The finding of a paleo-spruce timber in Hunshandak sandy land and its paleoecological significance, Sci. China Ser. D. 40 (1997) 599-604.

[11] Eckstein D., Baillie M.G.L., Egger H., Handbooks for archaeologists, No. 2. Dendrochronological dating. European Science Foundation, Strasbourg, 1984.

[12] Editing Committee for Vegetation of China, Vegetation of China, Science Press, Beijing, 1980. In Chinese.

[13] Feng X., Cui H., Tang K., Conkey L.E., Tree-ring $\delta D$ as an indicator of Asian Monsoon intensity, Quat. Res. 51 (1999) 262-266.

[14] Foster D.R., Disturbance history, community organization and vegetation dynamics of the old-growth Pisgah Forest, southwestern New Hampshire, USA, J. Ecol. 76 (1988) 105-134.

[15] Fritts H.C., Relationships of ring widths in arid-site conifers to variations in monthly temperature and precipitation, Ecol. Monograph. 44 (1974) 411-440.

[16] Fritts H.C., Tree Ring and Climate, Academic Press, London, 1976.

[17] Graumlich L.J., Response of tree growth to climatic variation in the mixed conifer and deciduous forests of the upper Great lakes region, Can. J. For. Res. 23 (1993) 133-143.

[18] Grissino-Mayer H.D., Swetnam T.W., Century-scale climate forcing of fire regimes in the American Southwest, Holocene 19 (2000) 213-220.

[19] Gutierrez E., Climate tree-growth relationships for Pinus uncinata Ram. in the Spanish pre-Pyrenees, Acta Oecologia 12(2) (1991) 213-225.

[20] Holmes R.L., Computer-assisted quality control in tree-ring dating and measurement, Tree-Ring Bull. 43 (1983) 69-78.

[21] Hughes M.K., Wu X., Shao X., Garfin G.M., A preliminary reconstruction of rainfall in North-central China since A.D. 1600 from tree-ring density and width, Quat. Res. 42 (1994) 88-99.

[22] Innes J.L., Forest decline, Progr. Phys. Geogr. 16 (1992) 1-64.

[23] Jacoby G.C., D'Arrigo R.D., Pederson N., Buckley B., Dugarjav C., Mijiddorj R., Temperature and precipitation in Mongolia based on dendroclimatic investigations, IAWA J. 20 (1999) 339-350.

[24] Jenkins M.A., Pallardy S.G., The influence of drought on red oak group species growth and mortality in the Missouri Ozarks, Can. J. For. Res. 25 (1995) 1119-1127.

[25] Johnson E.A., Miyanishi K., Kleb H., The hazards of interpretation of static age structure as shown by stand reconstructions in a Pinus contorta - Picea engelmannii forest, J. Ecol. 82 (1994) 923-931.

[26] Kienast F., Schweingruber F.H., Brräker O.U., Schrär E., Tree-ring studies on conifers along ecological gradients and the potential of single-year analyses, Can. J. For. Res. 17 (1987) 683-696.

[27] Krause C., Eckstein D., Dendrochronology of roots, Dendrochronologia 11 (1993) 9-23.

[28] Landmann G., Becker M., Delatour C., Dreyer E., Dupouey J.L., Oak dieback in France: historical and recent records, possible causes, current investigations, in: Bayerische Academie der Wissenschaften (Ed.), Zustand und Gefährdung der Laubwälder, Rundgespräche der Kommission für Ökologie 5, 1993, 97-113. 
[29] Lebourgeois F., Lévy G., Aussenac G., Clerc B., Willm F., Influence of soil drying on leaf water potential, photosynthesis, stomatal conductance and growth in two black pine varieties, Ann. Sci. For. 55 (1998) 287-299.

[30] Liang E., Shao X., Hu Y., Lin J., Dendroclimatic evaluation of climate-growth relationships of Meyer spruce (Picea meyeri) on a sandy substrate in semi-arid grassland, north China, Trees 15 (2001) 230-235.

[31] Lorimer C.G., Methodological considerations in the forest disturbance history, Can. J. For. Res. 15 (1985) 200-213.

[32] Mäkinen H., Nöjd P., Mielikäinen K., Climatic signal in annual growth variation in damaged and healthy stands of Norway spruce (Picea abies (L.) Karst.) in southern Finland, Trees 15 (2001) 177-185.

[33] Mast J.N., Veblen T.T., Thomas T., A dendrochronological method of studying tree mortality patterns, Phys. Geogr. 15 (1994) 529-542.

[34] Meko D.M., Stockton C.W., Boggess W.R., The tree-ring record of severe sustained drought, Water Resources Bull. 31 (1995) 789-801.

[35] Nicault A., Rathgeber C., Tessier L., Thomas A., Observations sur la mise en place du cerne chez le pin d'Alep (Pinus halepensis Mill.) : confrontation entre les mesures de croissance radiale, de densité et les facteurs climatiques, Ann. For. Sci. 58 (2001) 769-784. In French with English summary.

[36] Oberhuber W., Stumböck M., Kofler W., Climate tree-growth relationships of Scots pine stands (Pinus sylvestris L.) exposed to soil dryness, Trees 13 (1998) 19-27.

[37] Ogle K., Whitham T.G., Cobb N.S., Tree-ring variation in pinyon predicts likelihood of death following severe drought, Ecology 81 (2000) 3237-3243.

[38] Parker A.J., Parker K.C., Faust T.D., Fuller M.M., The effects of climatic variability on radial growth of two varieties of sand pine (Pinus clausa) in Florida, USA, Ann. For. Sci. 58 (2001) 333-350

[39] Payette S., Fortin M.-J., Morneau C., The recent sugar maple decline in southern Quebec: probable causes deduced from tree rings, Can. J. For. Res. 26 (1996) 1069-1078.

[40] Pedersen B.S., The role of stress in the mortality of Midwestern oaks indicated by growth prior to death, Ecology 79 (1998) 79-93.

[41] Pederson N., Jacoby G.C., D'Arrigo R.D., Cook E.R., Buckley B.M., Dugarjav C., Mijiddorj R., Hydrometeorological reconstructions for Northeastern Mongolia derived from tree rings: AD \&1651-1995, J. Clim. 14 (2001) 872-881.

[42] Rigling A., Waldner P.O., Forster T., Bräker O.U., Pouttu A., Ecological interpretation of tree-ring width and intraannual density fluctuations in Pinus sylvestris on dry sites in the central Alps and Siberia, Can. J. For. Res. 31 (2001) 18-31.

[43] Rolland C., Tree-ring and climatic relationships for Abies alba in the internal Alps, Tree-ring Bull. 53 (1993) 1-11.
[44] Rozas V., Detecting the impact of climate and disturbance on treering of Fagus Sylvatica L., and Quercus robur L. in a lowland forest in Cantabria, Northern Spain, Ann. For. Sci. 58 (2001) 237-251.

[45] Savage M., Anthropogenic and natural disturbance and patterns of mortality in a mixed conifer forest in California, Can. J. For. Res. 24 (1994) 1149-1159.

[46] Schweingruber F.H., Eckstein D., Serre-Bachet F., Bäker O.U., Identification, presentation and interpretation of event years and pointer years in dendrochronology, Dendrochronologia 8 (1990) 9-18.

[47] Schweingruber F.H., Briffa K.R., Nogler P., a tree-ring densitometric transect from Alska to Labrador, Int. J. Biometeorol. 37 (1993) 151-169.

[48] Shao X., Wu X., Tree-ring chronologies for Pinus armandi Franch from Huashan, China, Acta Geog. Sin. 49 (1994) 174-181. In Chinese with English summary.

[49] Swetnam T.W., Fire history and climate change in giant sequoia groves, Science 262 (1993) 885-889.

[50] Tardif J., Bergeron Y., Comparative dendroclimatological analysis of two black ash and two white cedar populations from contrasting sites in the Lake Duparquet region, northwestern Quebec, Can. J. For. Res. 27 (1997) 108-116.

[51] Tessier L., Nola P., Serre-Bachet F., Deciduous Quercus in the Mediterranean region: tree-ring/climate relationships, New Phytol. 126 (1994) 355-367.

[52] Villalba R., Veblen T.T., Influences of large-scale climatic variability on episodic tree mortality in northern Patagonia, Ecology 79 (1998) 2624-2640.

[53] Woodhouse C.A., Overpeck J.T., 2000 years of drought variability in the central United States, Bull. Amer. Meteor. Soc. 79 (1998) 2693-2714.

[54] Xu G., Climate change in arid and semiarid regions of China, China Meteorological Press, Beijing, 1997, pp. 85-101. In Chinese.

[55] Xu H., Chinese pine, China Forestry Publishing House, Beijing, 1990. In Chinese.

[56] Xu W., Zou C., Sandy forest ecosystem of China, China Forestry Publishing House, Beijing, 1998, pp. 14-63. In Chinese.

[57] Zhan J., The dendroclimate's reconstruction and dendroclimate's regional differentiation research in eastern and western agricultureanimal husbandry zone in Inner Mongolia, M.Sc. thesis, Beijing Normal University, Beijing, 1994, 36 p. In Chinese with English summary.

[58] Zhao X., Yao Y., Yang R., Ecological geographical characteristics and outlook of natural grasslands resources in Xilin river basin, In: Inner Mongolia Research Station of Academia Sinica (Ed.), Research on Grassland Ecosystem, Science Press, Beijing, Vol. 3. 1988, pp. 184-226. In Chinese with English summary. 